DOI: $10.15193 /$ zntj/2021/126/373

\author{
LUCYNA DYMIŃSKA, ABDULADHIM MOAMER M. ALBEGAR, \\ ADAM ZAJĄC, TADEUSZ CZUJ, WOJCIECH SĄSIADEK, \\ JADWIGA LORENC, JERZY HANUZA
}

\title{
APPLYING ADDITIVITY RULE TO DETERMINE PHYSICO-CHEMICAL PROPERTIES OF EDIBLE OIL BLENDS BASED ON KNOWN PARAMETERS OF COMPONENT OILS
}

\author{
S u m m a r y
}

In the paper, a procedure was suggested for making plant oil blends of desirable physico-chemical and performance parameters. There was applied a rule of additivity of parameters of component oils in the blend to get oil products with modified nutritional characteristics. The other objective of the research study was to test the usefulness of the procedure when projecting thermal properties of the blends for deep frying.

To make oil blends, plant oils were used that were produced by Oleofarm Ltd. The oil blends were analysed using chromatographic and spectroscopic methods. Their chemical parameters constituted an input dataset to make blends of expected performance properties. It was shown experimentally that it was possible to theoretically project physico-chemical and thermal parameters of the final oil blend. When knowing the chemical parameters of individual blend-forming oils, it is possible to employ them to determine the parameters of the final blend. There were suggested oil compositions for the preparation of advantageous blends to be used for deep frying and salad dressings. Thus there was confirmed the purposefulness of blending the oils in order to make products the qualities of which could be geared to the specific utility purposes.

Key words: plant oil, oil blends, additivity rule, FT-IR/ATR

\section{Introduction}

Two production processes intentionally involve the replacement of one ingredient with another one or the mixing of two or more products. Adulteration of food products

Dr hab. L. Dymińska, dr A. Zajac, dr W. Sasiadek, dr hab. J. Lorenc, prof. UEW, Katedra Chemii Bioorganicznej, Wydz. Inżynierii Produkcji, Uniwersytet Ekonomiczny we Wrocławiu, ul. Komandorska 118/120, 53-345 Wroctaw, dr A.M.M. Albegar, Faculty of Agriculture, Azzaytuna University, Bani Walid, Libya, mgr T. Czuj, Katedra Genetyki, Hodowli Roślin i Nasiennictwa, Wydz. PrzyrodniczoTechnologiczny, Uniwersytet Przyrodniczy we Wrocławiu, pl. Grunwaldzki 24A, 50-363 Wroctaw, prof. dr hab. J. Hanuza, Instytut Niskich Temperatur i Badań Strukturalnych PAN, ul. Okólna 2, 50-422 Wrocław. Kontakt: lucyna.dyminska@ue.wroc.pl 
is one of them. It takes place in the case of high-cost and high-quality oils, e.g. olive oil, which are often subjected to adulteration with other edible oils of a lower value [14]. This type of falsification affects the quality of fine oil and food, where olive oil is a component [5]. The second process often applied to oils is blending the products derived from many different varieties, regions and countries. Sometimes the oils from various sources and years are blended to create an individual taste. Moreover, some oils are suitable for high-temperature frying, above $230{ }^{\circ} \mathrm{C}$, owing to their high smoke point. Particularly the following oils are preferred for cooking in different countries: avocado, palm, peanut, rice bran, safflower, sesame and sunflower [6]. Palm oil contains more saturated fats than other oils and therefore it can resist high heat during deep frying and oxidation in comparison with the highly unsaturated vegetable oils. The oils are often blended to create the most suitable blend for high-temperature frying and baking [8].

The thermal behaviour of rice bran, sunflower oils and their blends was examined in terms of changes in their physico-chemical parameters, such as acid value, iodine value, colour value, peroxide value and fatty acids content. The analysed oils and their blends were used to deep fry dried potato chips in the repeated deep frying processes; those oils and their blends showed excellent thermal stability. Particularly useful proved model blends consisting of $60 \%$ of rice bran oil and $40 \%$ of sunflower oil [18]. Similar research studies were conducted for blended and interesterified mixtures of coconut oil or palm oil with rice bran oil or sesame oil. Their compositions and thermal profiles were determined by differential scanning calorimetry and an HPLC technique [22].

Tekin et al. [25] selected other oils to study physico-chemical changes induced by heat at the frying temperatures. They determined chemical (free fatty acids content, peroxide value, iodine value) and physical (viscosity, refractive index, colour) properties of hazelnut, olive-pomace, grapeseed and sunflower oils. The best thermal performances were found for hazelnut and olive-pomace oils [25]. Moreover, hazelnut oil was found to exhibit better stability than those of corn and sunflower oils [28]. The thermal stability of selected active components (mainly phenolic compounds) of extra virgin olive oil was analysed and it was found that the conventional heating caused their clear degradation [1].

In addition, the research was conducted on the stability of essential oils stored under different conditions [27]. Using chromatographic and chemical methods, there were studied oxidative changes in sunflower, grape seed, soybean, corn and olive oils caused by a frying temperature. It was reported that olive oil had a better stability against thermal oxidation compared to those of polyunsaturated oils. On the other hand among the unsaturated oils, corn and soybean oils are most resistant to degradation at a frying temperature [20]. 
The majority of recent reports show the results of chemical studies that were a basis for analysing the effects coming up at high temperatures. The blending mixtures of palm and sesame oils in different ratios were researched to get low cost blends of a better nutritional value [26]. The effect of the heat temperature on soybean oil was estimated in terms of its harmful consequences and health hazards when consuming food products fried in a degraded oil [2]. It was reported that, by adding antioxidants, the resistance of vegetable oils was improved in the thermal degradation process during frying. The researches included rapeseed, sesame, sunflower and palm oils [21]. The effect of thermal oxidation was studied on the example of arachis oil that has a high smoke point and intense color originating from the high content of $\beta$-carotene and lutein [11]. To analyse the thermal degradation of rapeseed oils and olive, there was applied an ultra-fast gas chromatography coupled with chemometrics. It was demonstrated that the adding of olive oil caused the stability of rapeseed oil to improve, and its flavour and aroma profile to change [19].

As for the blending and adulteration processes, the mixture of oils is randomly selected so that no distinct chemical composition and information about physical and chemical parameters of the final blend are retained. Some physical, chemical and thermal parameters of the final mixture can be theoretically projected provided the characteristics of the primary components are known. Those parameters can become the input data to be utilised in theoretical evaluations. The additivity rule enables to determine the quantitative amounts of particular components so as to make a blend of required properties for special culinary and frying applications.

The objective of the research study was to develop a procedure for making oil blends with desirable chemical properties and composed of individual oils with known parameters using an additivity rule.

\section{Material and methods}

All the oils used were produced in 2018 by Oleofarm Ltd. (Wrocław, Poland). Studied were seven edible oils: palm, coconut, rice, rapeseed, flax seed, sunflower and safflower, together with ten blends composed of those oils. The oils named were used to make mixtures. Refined oils were utilised and tested for deep frying as were virgin oils for salad dressings. The oil mixtures for deep frying were made by blending palm, coconut, rice bran and rapeseed oils (respectively: 1:1:0:0, 2:2:1:1, 1:2:1:1, 1:0:1:1, $1: 1: 1: 0$, where the numbers denote the amount of respective oil in the mixture). The oil mixtures for salad dressings were made by blending safflower, flax seed, sunflower and rapeseed oils (respectively: 1:1:2:2, 1:0:1:1, 1:1:2:1, 1:0:0:1, 0:0:1:1).

The fatty acid composition of the oils was determined according to the procedure described in ISO 5508:1990 [17]. The content of fatty acid methyl esters was measured with an Agilent 7890A gas chromatograph (Agilent Technologies Inc, USA) equipped 
with a FID detector and an Omegawax 250 column $(30 \mathrm{~m} \times 0.25 \mathrm{~mm} \times 0.25 \mu \mathrm{m})$. The operating conditions of the chromatograph were as follows: injector temperature $250^{\circ} \mathrm{C}$, split - 100:1, gas pressure $-17.81 \mathrm{psi}$, carrier gas - nitrogen, oven program $140{ }^{\circ} \mathrm{C}$ (for $\left.2 \mathrm{~min}\right)$ to $240{ }^{\circ} \mathrm{C}\left(4{ }^{\circ} \mathrm{C} / \mathrm{min}\right.$, for $\left.10 \mathrm{~min}\right)$, FID detector temperature $260^{\circ} \mathrm{C}$. Fatty acids methyl esters were identified and quantified by comparing the retention time and area of the peaks using 37 Fame Mix (Supelco, Sigma-Aldrich, USA) methyl ester standards. Each sample was esterified and measured in three replicates.

The iodine value (IV) was determined according to the procedure described in the ISO 3961:2018 [16]. The obtained experimental iodine values determined by the chemical method were compared with those obtained with the use of an IR method as described in the previous paper [9]. The FT-IR/ATR spectra were recorded in the range from 300 to $4000 \mathrm{~cm}^{-1}$ using a Nicolet 6700 spectrometer (International Equipment Trading Ltd., USA) equipped with a portable ATR set. Each sample was measured in three replicates. The iodine values were obtained based on the linear equation $\mathrm{I}_{\mathrm{v}(\mathrm{C}=\mathrm{C})} / \mathrm{I}_{\mathrm{v}(\mathrm{CH} 2)}=7.449 \times 10^{-4} \times \mathrm{IV}-0.0339$ as reported in the previous work [9]. The correlation coefficient of this relationship was 0.988 and showed a very good consistency between the calculated and measured data.

The smoke point was determined according to the Open Cup Method - the AOCS Official Method Cc 9a-48 [12]. The sample was put in a cup. The temperature was recorded by a thermometer placed vertically at the centre of the cup. The cup with the sample was rapidly heated up to $50{ }^{\circ} \mathrm{C}$ and then heating was controlled at a rate of $5{ }^{\circ} \mathrm{C} / \mathrm{min}$. The smoke point was recorded, when the oil sample reached a continuous stream of bluish smoke.

Based on the empirical research published by CHOPIN Technologies (France) [4], the additivity rule was used to calculate the alveographical parameters describing the final physicochemical properties of the oleic mixture, where the partial parameters of the composing oils were known. The following mathematical rule was applied:

$$
\text { Mixture parameter }=\frac{\mathrm{X}_{\mathrm{a}} \times \mathrm{P}_{\mathrm{a}}+\mathrm{X}_{\mathrm{b}} \times \mathrm{P}_{\mathrm{b}}+\mathrm{X}_{\mathrm{c}} \times \mathrm{P}_{\mathrm{c}}+\ldots}{100}=\frac{\sum(\mathrm{i}) \mathrm{X}_{\mathrm{i}} \times \mathrm{P}_{\mathrm{i}}}{100}
$$

where:

$\mathrm{X}_{\mathrm{i}}$ - dimensionless percentage amount of "i" oil in the entire mixture

$\mathrm{P}_{\mathrm{i}}-$ chemical or physical parameter describing the properties of "i" oil.

Based on this equation, it is possible to calculate the values of parameters of the mixture by substituting the respective percentage values of the component oils. The 
resulting final parameter of the mixture was compared with those determined experimentally.

\section{Results and discussion}

\section{Oil blends for deep frying}

In many papers $[3,7,15,24,29,30]$ there were studied, analysed and reviewed the physico-chemical changes induced by heating oils at frying temperatures. The spectroscopic methods are rarely applied in the research studies on thermal changes in vegetable oils. The heat-induced degradation of carotenoids in extra virgin olive oil was studied during microwave and conventional heating processes [10]. In the past, the changes were analysed in Raman spectra [29] and IR spectra of heated oils [15].

In the above cited papers it was reported that oil blends used for baking, light- or deep frying, searing, dressings for pasta, salad and breakfast refreshment were supposed to have different properties. The combination of a few natural oils used for hightemperature frying should result in a high smoke point, and toxins and free radicals should not be formed during heating [7]. Exposing the oils to high temperatures and oxygen causes a process called oxidation.

During deep frying by-products called "cooking oil polar compounds" are formed. Those residues increase the probability of heart disease; they can raise blood pressure and cholesterol levels. Therefore, while selecting oils to make an oil blend, a few known rules should be taken into account. Particular attention should be paid to smoke points of the oils constituting the blend.

The smoke point is a temperature value, at which oils start to decompose, lose nutrients and develop off-flavours. Some oils are particularly useful for high-heat treatment like deep frying and searing. The high smoke points have oils made from: corn $\left(230-236{ }^{\circ} \mathrm{C}\right)$, palm $\left(225-230^{\circ} \mathrm{C}\right)$, peanut $\left(225-231{ }^{\circ} \mathrm{C}\right)$, rapeseed $\left(200-205{ }^{\circ} \mathrm{C}\right)$, rice bran $\left(250-255^{\circ} \mathrm{C}\right)$, safflower $\left(230-265^{\circ} \mathrm{C}\right)$, semi-refined sesame $\left(210-230^{\circ} \mathrm{C}\right)$, soya bean $\left(230-245^{\circ} \mathrm{C}\right)$, sunflower $\left(230-250^{\circ} \mathrm{C}\right)$ and extra-light olive $\left(\sim 240^{\circ} \mathrm{C}\right)$.

Another parameter that should be considered when blending oils for deep frying is the content of saturated (SFA), monounsaturated fats (MUFA) and polyunsaturated fats (PUFA). Their ratio affects the stability of oil blends at high temperatures because the saturated fats are less susceptible to oxidation, whereas MUFAs are less sensitive to heat and oxidation than PUFAs during repeated heating. Physicochemical parameters of a wide class of the most popular oils are presented in Tab. 1. The acid profiles, iodine, acidic, peroxide and soaping values of some of these oils were given in the available reports $[9,13,23]$. 
Table 1. Amounts of fatty acids and smoke point of selected plant oils

Tabela 1. Udział kwasów tłuszczowych i punkt dymienia wybranych olejów roślinnych

\begin{tabular}{|c|c|c|c|c|}
\hline \multirow{2}{*}{$\begin{array}{l}\text { Type of oil } \\
\text { Rodzaj oleju }\end{array}$} & SFA & MUFA & PUFA & \multirow{2}{*}{$\begin{array}{c}\text { Smoke point } \\
\text { Punkt dymienia } \\
{\left[{ }^{\circ} \mathrm{C}\right]}\end{array}$} \\
\hline & \multicolumn{3}{|c|}{$[\%]$} & \\
\hline Avocado / Z awokado & 12 & $71 \div 74$ & $12 \div 14$ & 271 \\
\hline Coconut / Kokosowy & $84 \div 92$ & 6 & $1 \div 2$ & $175 \div 177$ \\
\hline Corn / Kukurydziany & $12 \div 13$ & $24 \div 25$ & $57 \div 62$ & $230 \div 236$ \\
\hline Cotton seed / Z nasion bawełny & $24 \div 25$ & $17 \div 26$ & $50 \div 57$ & $216 \div 230$ \\
\hline Flax seed / Z nasion lnu & 11 & 21 & 68 & 107 \\
\hline Ghee / Z ghi & & & & 250 \\
\hline Grape seed / Z pestek winogron & 12 & 17 & 71 & 204 \\
\hline Hemp / Konopny & 9 & 12 & 79 & 165 \\
\hline Olive / Oliwa & $13 \div 14$ & $71 \div 73$ & $9 \div 11$ & $160 \div 190$ \\
\hline Palm / Palmowy & $48 \div 52$ & $36 \div 38$ & $9 \div 10$ & $225 \div 230$ \\
\hline Palm kernel / Z ziarna palmowego & 79 & 11 & 1 & 330 \\
\hline Peanut / Z orzeszków ziemnych & 18 & 49 & 33 & $225 \div 231$ \\
\hline Rice bran / Z otrąb ryżowych & $20 \div 25$ & $38 \div 47$ & $33 \div 34$ & $254 \div 255$ \\
\hline Rapeseed / Rzepakowy & $6 \div 7$ & $59 \div 62$ & $29 \div 32$ & $204 \div 240$ \\
\hline Safflower / Krokoszowy & 10 & 13 & 77 & $160 \div 265$ \\
\hline Sesame (semi raf.) / Sezamowy & 14 & $39 \div 43$ & $40 \div 43$ & $210 \div 232$ \\
\hline Soya bean / Sojowy & $14 \div 15$ & $23 \div 24$ & $55 \div 61$ & $230 \div 241$ \\
\hline $\begin{array}{l}\text { Sunflower (linoleic, raf.) } \\
\text { Słonecznikowy (linolowy) }\end{array}$ & $10 \div 14$ & $19 \div 20$ & $64 \div 72$ & $160 \div 246$ \\
\hline $\begin{array}{l}\text { Sunflower (high oleic, raf.) } \\
\text { Słonecznikowy (wysokooleinowy) }\end{array}$ & 9 & 82 & 9 & 225 \\
\hline Walnut (semi raf.) / Z orzechów włoskich & 9 & 23 & 63 & 204 \\
\hline
\end{tabular}

Explanatory notes / Objaśnienia:

SFA - Saturated Fatty Acid / kwasy thuszczowe nasycone; MUFA - Monounsaturated Fatty Acid / kwasy tłuszczowe jednonienasycone; PUFA - Polyunsaturated Fatty Acid / kwasy tłuszczowe wielonienasycone. Source / Źródło: the authors' own study based on [1, 22, 28] / opracowanie własne na podstawie [1, 22, 28]

Of the oils listed in Tab. 1 four oils were preliminarily selected as the best components to make a blended mix for deep frying use. The following oils were used in the composition of those mixtures: palm, coconut, rice and rapeseed oil. They were characterised by a higher amount of SFA and a low amount of total MUFA + PUFA. Those oils were selected as the most advantageous oils for the preparation of model oil blend for deep frying. Moreover, determined were the composition and thermal profiles of the mixtures made from coconut oil or palm oil with rice bran oil or sesame oil and their stability during heating at a high temperature was proved. The blends with the highest amount of SFA fraction and the lowest amount of MUFA + PUFA fraction along with the highest smoke point can have suitable properties for the deep frying process. Fatty acid profiles of oils used to make blends are presented in Tab. 2. 
Table 2. Fatty acid profile of oils used to make oil blends

Tabela 2. Profil kwasów tłuszczowych olejów stosowanych do przygotowania mieszanek

\begin{tabular}{|c|c|c|c|c|c|c|c|}
\hline \multirow{2}{*}{ 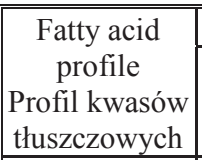 } & \multicolumn{7}{|c|}{ OOils / Oleje } \\
\hline & $\begin{array}{c}\text { Palm } \\
\text { Palmowy }\end{array}$ & $\begin{array}{c}\text { Coconut } \\
\text { Kokosowy }\end{array}$ & $\begin{array}{l}\text { Rice bran } \\
\mathrm{Z} \text { otrąb } \\
\text { ryżowych }\end{array}$ & $\begin{array}{c}\text { Rapeseed } \\
\text { Rzepakowy }\end{array}$ & $\begin{array}{l}\text { Safflower } \\
\text { Sezamowy }\end{array}$ & $\begin{array}{c}\text { Flax seed } \\
\text { Z nasion } \\
\operatorname{lnu} \\
\end{array}$ & $\begin{array}{c}\text { Sunflower } \\
\text { Słonecznikowy }\end{array}$ \\
\hline $\mathrm{C} 4: 0$ & 1.74 & 2.39 & 2.54 & 1.76 & 1.51 & 1.67 & 1.19 \\
\hline C6:0 & 0.00 & 0.80 & 0.00 & 0.00 & 0.00 & 0.00 & 0.00 \\
\hline $\mathrm{C} 8: 0$ & 0.03 & 8.61 & 0.01 & 0.00 & 0.00 & 0.00 & 0.00 \\
\hline $\mathrm{C} 10: 0$ & 0.03 & 6.14 & 0.01 & 0.01 & 0.00 & 0.00 & 0.00 \\
\hline $\mathrm{C} 12: 0$ & 0.33 & 47.70 & 0.03 & 0.02 & 0.01 & 0.01 & 0.01 \\
\hline C13:0 & 0.01 & 0.04 & 0.01 & 0.01 & 0.01 & 0.01 & 0.01 \\
\hline C14:0 & 0.67 & 18.15 & 0.18 & 0.05 & 0.10 & 0.05 & 0.04 \\
\hline C16:0 & 38.04 & 7.70 & 9.42 & 4.31 & 5.82 & 6.11 & 3.70 \\
\hline C16:1 & 0.18 & 0.01 & 0.15 & 0.23 & 0.06 & 0.10 & 0.12 \\
\hline $\mathrm{C} 17: 0$ & 0.13 & 0.05 & 0.09 & 0.10 & 0.07 & 0.11 & 0.08 \\
\hline C18:0 & 4.35 & 2.78 & 2.89 & 1.63 & 2.43 & 3.97 & 2.50 \\
\hline $\begin{array}{c}\mathrm{C} 18: \ln 9 \mathrm{t}+ \\
\mathrm{C} 18: \ln 9 \mathrm{c}\end{array}$ & 44.30 & 4.30 & 45.02 & 61.26 & 13.03 & 16.23 & 84.71 \\
\hline $\mathrm{C} 18: 2 \mathrm{n} 6 \mathrm{c}$ & 8.49 & 0.65 & 37.52 & 18.84 & 75.23 & 68.61 & 5.52 \\
\hline $\mathrm{C} 18: 3 \mathrm{n} 3$ & 0.32 & 0.00 & 0.30 & 8.94 & 0.24 & 2.36 & 0.05 \\
\hline C20:0 & 0.37 & 0.11 & 0.35 & 0.55 & 0.32 & 0.13 & 0.24 \\
\hline $\mathrm{C} 20: \ln 9$ & 0.16 & 0.12 & 0.27 & 1.23 & 0.18 & 0.14 & 0.26 \\
\hline C20:2 & 0.00 & 0.00 & 0.018 & 0.07 & 0.03 & 0.07 & 0.00 \\
\hline $\mathrm{C} 21: 0$ & 0.00 & 0.00 & 0.02 & 0.03 & 0.00 & 0.00 & 0.00 \\
\hline $\mathrm{C} 20: 4 \mathrm{n} 6$ & 0.00 & 0.00 & 0.00 & 0.00 & 0.03 & 0.00 & 0.00 \\
\hline $\mathrm{C} 22: 0$ & 0.07 & 0.18 & 0.63 & 0.32 & 0.22 & 0.15 & 0.91 \\
\hline C22:1n9 & 0.09 & 0.00 & 0.10 & 0.22 & 0.25 & 0.07 & 0.02 \\
\hline $\mathrm{C} 22: 2$ & 0.15 & 0.00 & 0.00 & 0.00 & 0.00 & 0.02 & 0.00 \\
\hline C23:0 & 0.10 & 0.00 & 0.05 & 0.02 & 0.02 & 0.14 & 0.05 \\
\hline C24:0 & 0.23 & 0.06 & 0.41 & 0.18 & 0.17 & 0.05 & 0.45 \\
\hline $\begin{array}{c}\mathrm{C} 22: 6 \mathrm{n} 3+ \\
\mathrm{C} 24: 1 \mathrm{n} 9\end{array}$ & 0.23 & 0.20 & 0.00 & 0.23 & 0.24 & 0.00 & 0.15 \\
\hline
\end{tabular}

Fatty acid profiles of oils used to make oil mixtures as proposed by the authors in their own study are shown in Tab. 3. Those oils were utilised to make oil blends for deep frying and salad dressings based on the assumption of their additivity. Data referring to the amounts of the saturated, monounsaturated and polyunsaturated fractions in those oils are presented in Tab. 4. 
Table 3. Fatty acid profile of blended oil mixtures

Tabela 3. Profil kwasów thuszczowych mieszanin olejowych

\begin{tabular}{|c|c|c|c|c|c|c|c|c|c|c|}
\hline \multirow[b]{2}{*}{$\begin{array}{l}\text { Fatty acid } \\
\text { profile } \\
\text { Profil kwasów } \\
\text { tłuszczowych }\end{array}$} & \multicolumn{10}{|c|}{ Blended oil mixtures / Mieszaniny olejowe } \\
\hline & 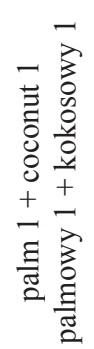 & 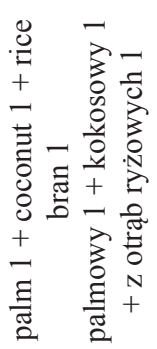 & 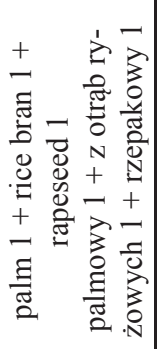 & 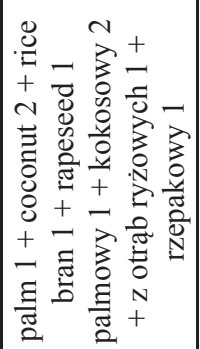 & 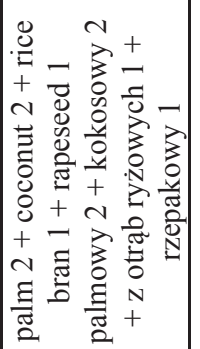 & 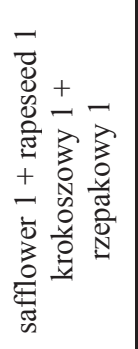 & 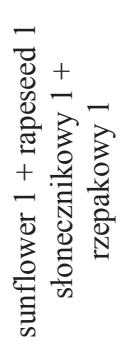 & 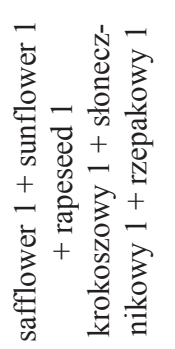 & 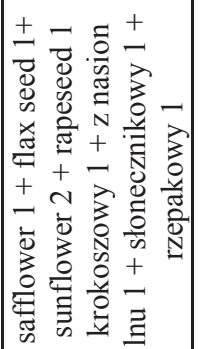 & 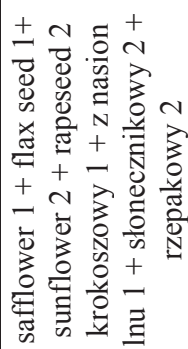 \\
\hline C4:0 & 1.73 & 1.78 & 0.19 & 0.33 & 0.28 & 0.27 & 0.31 & 0.30 & 0.30 & 0.21 \\
\hline C6:0 & 0.46 & 0.28 & 0.03 & 0.34 & 0.28 & 0.00 & 0.00 & 0.01 & 0.00 & 0.00 \\
\hline $\mathrm{C} 8: 0$ & 4.36 & 2.97 & 0.01 & 3.66 & 3.02 & 0.00 & 0.00 & 0.00 & 0.01 & 0.00 \\
\hline $\mathrm{C} 10: 0$ & 3.11 & 2.11 & 0.02 & 2.60 & 2.15 & 0.01 & 0.01 & 0.00 & 0.01 & 0.01 \\
\hline $\mathrm{C} 12: 0$ & 24.56 & 16.59 & 0.13 & 20.46 & 16.73 & 0.02 & 0.01 & 0.01 & 0.01 & 0.01 \\
\hline C13:0 & 0.00 & 0.00 & 0.00 & 0.02 & 0.02 & 0.01 & 0.01 & 0.01 & 0.01 & 0.01 \\
\hline C14:0 & 9.65 & 6.55 & 0.31 & 7.96 & 6.58 & 0.08 & 0.05 & 0.07 & 0.06 & 0.06 \\
\hline C16:0 & 23.02 & 18.50 & 17.16 & 13.57 & 17.58 & 5.11 & 4.04 & 4.66 & 4.78 & 4.71 \\
\hline C16:1 & 0.10 & 0.12 & 0.19 & 0.11 & 0.13 & 0.15 & 0.17 & 0.14 & 0.13 & 0.15 \\
\hline $\mathrm{C} 17: 0$ & 0.11 & 0.10 & 0.11 & 0.09 & 0.09 & 0.09 & 0.09 & 0.09 & 0.10 & 0.09 \\
\hline C18:0 & 3.68 & 3.43 & 3.00 & 2.95 & 3.18 & 2.06 & 2.09 & 2.22 & 2.65 & 2.49 \\
\hline $\begin{array}{c}\mathrm{C} 18: \ln 9 \mathrm{t}+ \\
\mathrm{C} 18: \ln 9 \mathrm{c}\end{array}$ & 24.05 & 31.73 & 51.08 & 31.53 & 34.06 & 37.44 & 73.89 & 53.31 & 52.51 & 54.19 \\
\hline $\mathrm{C} 18: 2 \mathrm{n} 6 \mathrm{c}$ & 4.70 & 14.07 & 22.31 & 12.90 & 12.60 & 47.72 & 12.28 & 33.78 & 35.22 & 32.69 \\
\hline $\mathrm{C} 18: 3 \mathrm{n} 3$ & 0.16 & 0.20 & 3.13 & 1.88 & 1.64 & 4.57 & 4.49 & 3.08 & 2.39 & 3.42 \\
\hline
\end{tabular}




\begin{tabular}{|c|l|l|l|l|l|l|l|l|l|l||}
\hline $\mathrm{C} 20: 0$ & 0.24 & 0.29 & 0.43 & 0.34 & 0.36 & 0.45 & 0.39 & 0.37 & 0.30 & 0.34 \\
\hline $\mathrm{C} 20: 1 \mathrm{n} 9$ & 0.09 & 0.14 & 0.54 & 0.33 & 0.31 & 0.71 & 0.75 & 0.57 & 0.43 & 0.54 \\
\hline $\mathrm{C} 20: 2$ & 0.00 & 0.00 & 0.04 & 0.00 & 0.02 & 0.05 & 0.04 & 0.04 & 0.04 & 0.04 \\
\hline $\mathrm{C} 21: 0$ & 0.00 & 0.00 & 0.00 & 0.00 & 0.00 & 0.00 & 0.00 & 0.02 & 0.02 & 0.01 \\
\hline $\mathrm{C} 20: 4 \mathrm{n} 6$ & 0.00 & 0.00 & 0.00 & 0.00 & 0.00 & 0.03 & 0.02 & 0.04 & 0.00 & 0.00 \\
\hline $\mathrm{C} 22: 0$ & 0.00 & 0.29 & 0.36 & 0.25 & 0.24 & 0.28 & 0.62 & 0.49 & 0.50 & 0.48 \\
\hline $\mathrm{C} 22: 1 \mathrm{n} 9$ & 0.00 & 0.00 & 0.14 & 0.09 & 0.09 & 0.26 & 0.12 & 0.18 & 0.14 & 0.16 \\
\hline $\mathrm{C} 23: 0$ & 0.00 & 0.24 & 0.25 & 0.19 & 0.20 & 0.22 & 0.21 & 0.26 & 0.04 & 0.03 \\
\hline $\mathrm{C} 24: 0$ & 0.00 & 0.50 & 0.50 & 0.35 & 0.39 & 0.32 & 0.31 & 0.25 & 0.28 & 0.26 \\
\hline $\begin{array}{c}\mathrm{C} 22: 6 \mathrm{n} 3+ \\
\mathrm{C} 24: 1 \mathrm{n} 9\end{array}$ & 0.16 & 0.17 & 0.06 & 0.04 & 0.08 & 0.18 & 0.10 & 0.13 & \multirow{2}{*}{0.08} & 0.10 \\
\hline
\end{tabular}

Explanatory notes / Objaśnienia:

Numbers next to the name of oil denote its volume applied to make oil blend / Liczby przy nazwie oleju oznaczają jego objętość stosowaną do przygotowania mieszaniny. 
Table 4. Theoretical and experimental physico-chemical parameters characterising individual oils and their blends for deep frying

Tabela 4. Teoretyczne i doświadczalne parametry fizykochemiczne charakteryzujące pojedyncze oleje i ich mieszanki do głębokiego smażenia

\begin{tabular}{|c|c|c|c|c|c|c|c|c|c|c|c|}
\hline \multicolumn{4}{|c|}{$\begin{array}{l}\text { Composition of oils studied and their } \\
\text { amounts in blended mix } \\
\text { Skład badanych olejów i ich ilość w mie- } \\
\text { szance }\end{array}$} & \multicolumn{8}{|c|}{$\begin{array}{l}\text { Physico-chemical parameters } \\
\text { Parametry fizykochemiczne }\end{array}$} \\
\hline \multirow{3}{*}{$\begin{array}{c}\text { palm } \\
\text { palmowy }\end{array}$} & \multirow{3}{*}{$\begin{array}{l}\text { coconut } \\
\text { kokosowy }\end{array}$} & \multirow{3}{*}{$\begin{array}{l}\text { rice bran } \\
\mathrm{z} \text { otrąb } \\
\text { ryżowych }\end{array}$} & \multirow{3}{*}{$\begin{array}{c}\text { rapeseed } \\
\text { rzepakowy }\end{array}$} & \multicolumn{2}{|c|}{ SFA } & \multirow{2}{*}{\multicolumn{2}{|c|}{$\frac{\text { MUFA }}{[\%]}$}} & \multirow{2}{*}{\multicolumn{2}{|c|}{ PUFA }} & \multirow{2}{*}{\multicolumn{2}{|c|}{$\begin{array}{c}\text { Smoke point } \\
\text { Punkt dymienia }\left[{ }^{\circ} \mathrm{C}\right]\end{array}$}} \\
\hline & & & & & & & & & & & \\
\hline & & & & $\begin{array}{c}\text { experimental } \\
\text { doświadczalne }\end{array}$ & $\begin{array}{l}\text { calculated } \\
\text { teoretyczne }\end{array}$ & \begin{tabular}{|c|} 
experimental \\
doświadczalne
\end{tabular} & $\begin{array}{c}\text { calculated } \\
\text { teoretyczne }\end{array}$ & $\begin{array}{c}\text { experimental } \\
\text { doświadczalne }\end{array}$ & \begin{tabular}{|c|} 
calculated \\
teoretyczne
\end{tabular} & $\begin{array}{c}\text { experimental } \\
\text { doświadczalny }\end{array}$ & \begin{tabular}{|l} 
calculated \\
teoretyczny
\end{tabular} \\
\hline 1 & 0 & 0 & 0 & 46.10 & 50 & 444.95 & 37 & $\begin{array}{l}9.18 \\
\end{array}$ & 9.5 & 212 & 227.7 \\
\hline 0 & 1 & 0 & 0 & 94.72 & 88 & 4.63 & 6 & 0.85 & 1.5 & 170 & 176.0 \\
\hline 0 & 0 & 1 & 0 & 16.81 & 22.5 & 45.55 & 42.5 & 37.83 & 33.5 & 244 & 254.5 \\
\hline 0 & 0 & 0 & 1 & 8.98 & 6.5 & 63.17 & 60.5 & 28.07 & 30.5 & 220 & 204.5 \\
\hline 1 & 1 & 0 & 0 & 69.70 & 69.00 & 25.44 & 21.50 & 4.96 & 5.6 & 164 & 201.75 \\
\hline 1 & 1 & 1 & 0 & 51.85 & 53.50 & 32.08 & 28.50 & 16.07 & 14.83 & 180 & 219.33 \\
\hline 1 & 2 & 1 & 1 & 53,12 & 51.00 & 32.10 & 30.40 & 14.82 & 15.30 & 190 & 207.70 \\
\hline 2 & 2 & 1 & 1 & 51.08 & 50.83 & 34.66 & 31.50 & 14.33 & 14.33 & 178 & 211.00 \\
\hline
\end{tabular}

Explanatory notes / Objaśnienia:

Calculated values are derived from Tab. 1 as averages of the data in reference literature / Obliczone wartości pochodzą z tab. 1 jako średnie $\mathrm{z}$ danych literaturo-

wych. Other explanatory notes as in Tab. 1. / Pozostałe objaśnienia jak pod tab. 1. 
The experimental and calculated values characterise the chemical properties of the blends under analysis. The experimentally determined amounts of the SFA, MUFA and PUFA fractions as well as the iodine value are close to those as predicted on the basis of the additivity rule applied for the oils constituting the blend. However the smoke points of the prepared blends that characterise their physical (thermal) properties differ significantly from those expected for the oil blends and calculated using the additivity rule for the partial values.

The parameters calculated with the use of the additivity procedure showed a good compatibility with the experimental data of the SFA, MUFA, PUFA as well as of the iodine value. It means that the final chemical properties of the blend can be projected based on the partial values of individual oils constituting the mixture. However the proper thermal parameters of the mixtures tested could not be achieved.

The results obtained in the authors' own study can also be used to recommend the best oil blend for the deep frying process. This oil mixture should have a high smoke point, a high content of saturation fraction (SFA) owing to low toxin and free radical formation during heating and a low content of unsaturated fraction (UFA). The highest amount of SFA occurs in the coconut oil $(94.7 \%)$, but its smoke point is too low $\left(170^{\circ} \mathrm{C}\right)$. The analysis of the data as presented in Tab. 4 enables to propose the best oil blend in terms of health. Such a mixture should consist of one part of palm oil, two parts of coconut oil, one part of rice bran oil and one part of rapeseed oil. The oil blend as suggested above is characterised by a high content of SFA $(53.1 \%)$ and a high
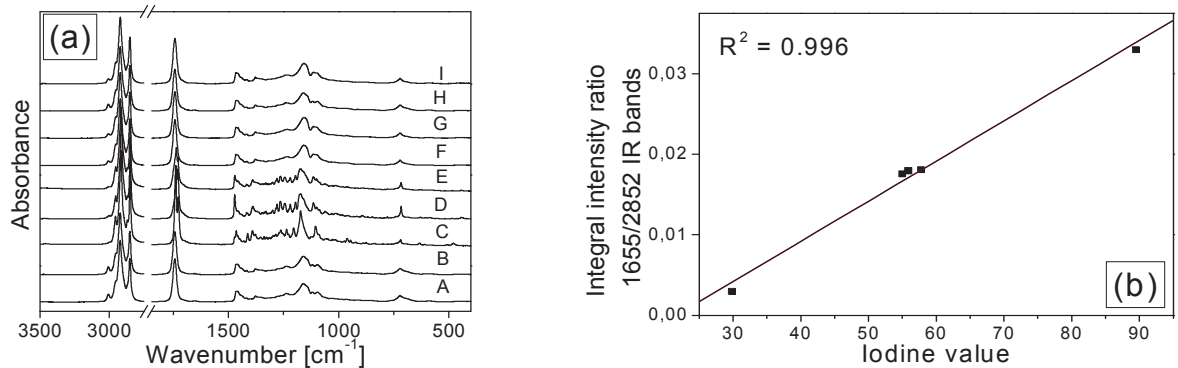

Explanatory notes / Objaśnienia:

Oils / Oleje: A - rapeseed / rzepakowy; B - rice bran / z otrąb ryżowych; C - coconut / kokosowy; D palm / palmowy; blends of oils (palm, coconut, rice bran, rapeseed) in proportion / mieszanki olejów (palmowego, kokosowego, z otrąb ryżowych, rzepakowego) w stosunku: $\mathrm{E}-1: 1: 0: 0 ; \mathrm{F}-2: 2: 1: 1$; G $1: 2: 1: 1 ; \mathrm{H}-1: 0: 1: 1 ; \mathrm{I}-1: 1: 1: 0$.

Fig. 1. (a) FT-IR spectra of studied oils and their blends; (b) Linear dependence between iodine value of blends and integral intensity of selected IR bands at $1655 / 2852 \mathrm{~cm}^{-1}$

Rys. 1. (a) Widma FT-IR badanych olejów i ich mieszanek; (b) Zależność liniowa między liczbą jodową mieszanek a integralną intensywnością wybranych pasm IR przy $1655 / 2852 \mathrm{~cm}^{-1}$ 
smoke point $\left(190^{\circ} \mathrm{C}\right)$. With the additivity rule applied, other mixtures showed favourable qualities in different technical applications.

It should be noted that the iodine value shows the same regularity as that described in the previous paper for a wide class of edible oils [9]. In Fig. 1a there are presented the IR spectra of the four studied oils and their mixtures. A linear dependence between the iodine value and integral intensities of the selected IR bands is shown in Fig. 1b. This correlation was drawn for the iodine values as presented in Tab. 5 .

Table 5. Theoretical and experimental iodine values (IV) of blends tested

Tabela 5. Teoretyczne i doświadczalne liczby jodowe (IV) badanych mieszanek

\begin{tabular}{|c|c|c|c|c|c|c|}
\hline \multicolumn{4}{|c|}{$\begin{array}{c}\text { Volume of respective oils } \\
\text { Objętość poszczególnych olejów }\end{array}$} & \multirow{2}{*}{$\begin{array}{l}\mathrm{IV}_{\mathrm{t}} \text { theoretical } \\
\text { teoretyczna }\end{array}$} & \multirow{2}{*}{$\begin{array}{l}\text { IV }_{\text {exp }} \text { experimental } \\
\text { doświadczalna }\end{array}$} & \multirow{2}{*}{$\begin{array}{c}\text { Compatibility* } \\
\text { Zgodność }\end{array}$} \\
\hline $\begin{array}{c}\text { palm } \\
\text { palmowy }\end{array}$ & $\begin{array}{l}\text { coconut } \\
\text { kokosowy }\end{array}$ & $\begin{array}{l}\text { rice bran } \\
\text { z otrąb } \\
\text { ryżowych }\end{array}$ & $\begin{array}{l}\text { rapeseed } \\
\text { rzepakowy }\end{array}$ & & & \\
\hline 1 & 1 & 0 & 0 & 29.84 & 29.82 & 0.06 \\
\hline 1 & 1 & 1 & 0 & 53.10 & 54.93 & 3.44 \\
\hline 1 & 0 & 1 & 1 & 85.19 & 89.46 & 5.02 \\
\hline 1 & 2 & 1 & 1 & 54.53 & 57.71 & 5.83 \\
\hline 2 & 2 & 1 & 1 & 53.96 & 55.84 & 3.47 \\
\hline
\end{tabular}

Explanatory note / Objaśnienie:

$*\left[\left(\mathrm{IV}_{\mathrm{t}}-\mathrm{IV}_{\mathrm{exp}}\right) \times 100\right] / \mathrm{IV}_{\mathrm{t}}[\%]$

\section{Blends of oils for salad dressings}

Regarding the oil mixture for salad-dressing an analysis was done that was similar to the one performed in the case of the blends designed for deep frying. The results presented in Tab. 6 confirm the trends found for the latter case. The parameters calculated using the additivity procedure showed a good compatibility with the experimental data of SFA, MUFA, PUFA. It means that the final chemical properties of the blend can be projected based on the partial values of individual oils constituting the mixture. Likewise in the case of oils for salad dressings, the proper thermal parameters of the mixtures tested could not be achieved.

The analysis of the Tab. 6 results shows that the healthiest mixture for salad dressings is a blend consisting of one part of sunflower oil and one part of rapeseed oil with only $8.15 \%$ of SFA. There were measured IR spectra of oils for salad dressings (Fig. 2a). In this case the correlation between the spectral parameters and PUFA content was considered. It was found that a linear relationship existed in the case of this type of blends too (Fig. 2b). 
Table 6. Theoretical and experimental parameters for blends designed for salad dressings

Tabela 6 . Teoretyczne i doświadczalne parametry mieszanek olejów przeznaczonych do sosów sałatkowych

\begin{tabular}{|c|c|c|c|c|c|c|c|c|c|c|c|}
\hline \multicolumn{4}{|c|}{$\begin{array}{c}\text { Volume of individual oils } \\
\text { Objętość poszczególnych olejów }\end{array}$} & \multicolumn{8}{|c|}{$\begin{array}{l}\text { Physico-chemical parameters } \\
\text { Parametry fizykochemiczne }\end{array}$} \\
\hline \multirow{3}{*}{ 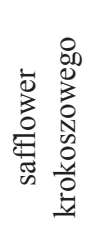 } & \multirow{3}{*}{ 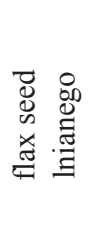 } & \multirow{3}{*}{ 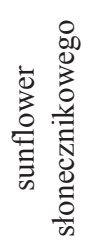 } & \multirow{3}{*}{ 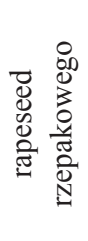 } & \multicolumn{2}{|c|}{ SFA } & \multicolumn{2}{|c|}{ MUFA } & \multirow{2}{*}{\multicolumn{2}{|c|}{ PUFA }} & \multirow{2}{*}{\multicolumn{2}{|c|}{$\begin{array}{c}\text { Smoke point } \\
\text { Punkt dymienia }\left[{ }^{\circ} \mathrm{C}\right]\end{array}$}} \\
\hline & & & & \multicolumn{4}{|c|}{ [\%] } & & & & \\
\hline & & & & $\begin{array}{c}\text { experimental } \\
\text { doświadczalne }\end{array}$ & $\begin{array}{c}\text { calculated } \\
\text { teoretyczne }\end{array}$ & $\begin{array}{l}\text { experimental } \\
\text { doświadczalne }\end{array}$ & $\begin{array}{l}\text { calculated } \\
\text { teoretyczne }\end{array}$ & $\begin{array}{l}\text { experimental } \\
\text { doświadczalne }\end{array}$ & $\begin{array}{c}\text { calculated } \\
\text { teoretyczne }\end{array}$ & $\begin{array}{c}\text { experimental } \\
\text { doświadczalny }\end{array}$ & $\begin{array}{l}\text { calculated } \\
\text { teoretyczny }\end{array}$ \\
\hline 1 & 0 & 0 & 0 & 10.66 & 10 & 13.77 & 13 & 75.81 & 77 & 210 & 247 \\
\hline 0 & 1 & 0 & 0 & 12.39 & 11 & 16.54 & 21 & 71.01 & 68 & 110 & 107 \\
\hline 0 & 0 & 1 & 0 & 9.18 & 9 & 85.26 & 82 & 5.71 & 9 & 230 & 225 \\
\hline 0 & 0 & 0 & 1 & 8.99 & 6.5 & 63.17 & 60.5 & 28.07 & 30.5 & 220 & 205 \\
\hline 1 & 0 & 0 & 1 & 8.90 & 8.25 & 38.73 & 36.75 & 52.54 & 53.75 & 202 & 226 \\
\hline 0 & 0 & 1 & 1 & 8.15 & 7.75 & 75.03 & 71.25 & 16.92 & 19.75 & 204 & 214 \\
\hline 1 & 0 & 1 & 1 & 8.75 & 8.50 & 54.32 & 51.83 & 37.06 & 38.83 & 200 & 225 \\
\hline 1 & 1 & 2 & 1 & 9.06 & 9.10 & 53.29 & 51.70 & 37.73 & 38.70 & 196 & 201 \\
\hline 1 & 1 & 2 & 2 & 8.71 & 7.96 & 55.14 & 53.17 & 36.25 & 37.33 & 192 & 202 \\
\hline
\end{tabular}



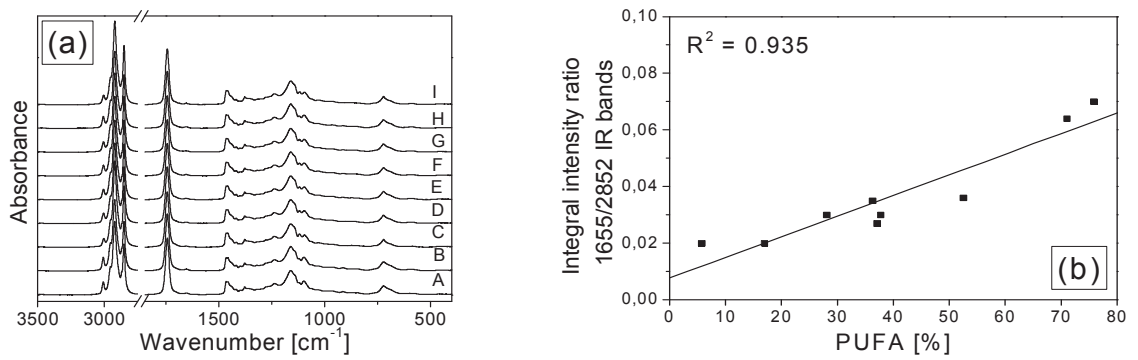

Explanatory notes / Objaśnienia:

Oils / Oleje: A - flax seed / lniany; B - safflower / krokoszowy; C - sunflower / słonecznikowy; D rapeseed / rzepakowy; blends of oils (safflower, flax seed, sunflower, rapeseed) in proportion / mieszanki olejów (krokoszowego, lnianego, słonecznikowego, rzepakowego) w stosunku: E - 1:1:2:2; F - 1:0:1:1; G $-1: 1: 2: 1 ; \mathrm{H}-1: 0: 0: 1 ; \mathrm{I}-0: 0: 1: 1$.

Fig. 2. (a) FT-IR spectra of oils studied and their blends; (b) Linear dependence between PUFA of oils and blends and the integral intensities of the IR bands at 1655/2852 $\mathrm{cm}^{-1}$

Rys. 2. (a) Widma FT-IR badanych olejów i ich mieszanek; (b) Liniowa zależność między PUFA olejów i mieszanin a intensywnościami integralnymi dla pasm IR przy 1655/2852 $\mathrm{cm}^{-1}$

\section{Thermal behaviour of oil blends}

The experimental values of smoke points differ from those as projected theoretically by the use of additivity rule for individual oils constituting the mixture (Tab. 4 and 6). Where the values of SFA, MUFA, and PUFA contents were related to the smoke points of the blends studied, a linear relationship between the smoke points and MUFA + PUFA contents was reported (Fig. 3). Thus, the smoke points of oil mixtures can depend mainly on the content of unsaturated fraction in the blend. However in this case the calculated discrepancy factor $\mathrm{R}^{2}$ is moderately good.

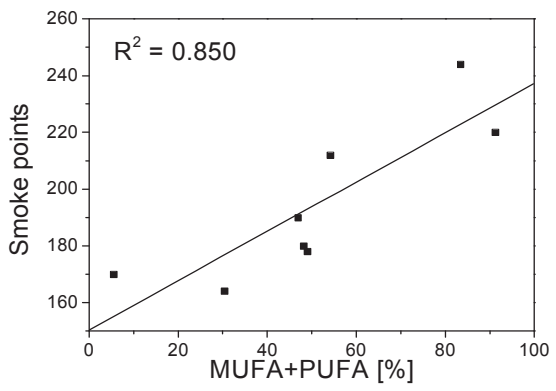

Fig. 3. Dependence between values of smoke points and MUFA + PUFA amounts in oils and blends designed for deep frying

Rys. 3. Zależność pomiędzy wartościami punktów dymienia a udziałem MUFA + PUFA w olejach i mieszaninach przeznaczonych do głębokiego smażenia 


\section{Conclusions}

1. When knowing the chemical parameters of individual oils constituting the mixture, it is possible to propose a blend of oils for special purposes.

2. By using an additivity method and based on the research conducted, sets of oil blends were projected for deep frying and salad dressings.

3. Mixing palm, coconut, rice bran and rapeseed oils proved to be the best blend for deep frying.

4. Mixing safflower, flax seed, sunflower and rapeseed oils proved to be the best blend for salad dressings.

5. It was confirmed that a linear relationship existed between the iodine values of the blends and integral intensities of the selected IR bands for individual edible oils.

6. The relationship between smoke points and overall MUFA and PUFA amounts was good.

\section{References}

[1] Attya M., Benabdelkamel H., Perri E., Russo A., Sindona G.: Effects of conventional heating on the stability of major olive oil phenolic compounds by tandem mass spectrometry and isotope dilution assay. Molecules, 2010, 15 (12), 8734-8746.

[2] Bastos Fernandes J.C., Draghi P.F.: Thermal stability of soybean oil: When must we discard it? MOJ Food Process. Technol., 2016, 2 (5), 170-174.

[3] Choe E., Min D.B.: Chemistry of deep-fat frying oils. J. Food Sci., 2007, 72 (5), R77-R86.

[4] CHOPIN Technologies: Materiały informacyjne. Pub. Polskie, 2001.

[5] Christy A.A., Kasemsumran S., Du Y., Ozaki Y.: The detection and quantification of adulteration in olive oil by near-infrared spectroscopy and chemometrics. Analytical Sciences, 2004, 20 (6), 935940.

[6] Chu M.: Kitchen notes: Smoke points of various fats. [on line]. Dostęp w Internecie [6.08.2020]: http://www.cookingforengineers.com/article/50/Smoke-Points-of-Various-Fats

[7] Das A.K., Babylatha R., Pavithra A.S., Khatoon S.: Thermal degradation of groundnut oil during continuous and intermittent frying. J. Food Sci. Technol., 2013, 50 (6), 1186-1192.

[8] De Marco E., Savarese M., Parisini C., Battimo I., Falco S., Sacchi R.: Frying performance of a sunflower/palm oil blend in comparison with pure palm oil. Eur. J. Lipid Sci. Technol., 2007, 109 (3), 237-246.

[9] Dymińska L., Calik M., Albegar A.M.M., Zając A., Kostyń K., Lorenc J., Hanuza J.: Quantitative determination of the iodine values of unsaturated plant oils using infrared and Raman spectroscopy methods. Intern. J. Food Properties, 2017, 20 (9), 2003-2015.

[10] El-Abassy R.M., Donfack P., Materny A.: Assessment of conventional and microwave heating induced degradation of carotenoids in olive oil by VIS Raman spectroscopy and classical methods. Food Res. Intern., 2010, 43 (3), 694-700.

[11] Falade A.O., Oboh G.: Thermal oxidation induces lipid peroxidation and changes in the physicochemical properties and $\beta$-carotene content of arachis oil. Intern. J. Food Sci., 2015, \#806524.

[12] AOCS Official Method Cc 9a-48. Smoke, Flash, and Fire Points, Cleveland Open Cup Method. 
[13] Firestone D. (Ed.): Physical and Chemical Characteristics of Oils, Fats, and Waxes. $2^{\text {nd }}$ ed. AOCS Press, Champaign, Illinois, 2006.

[14] Flores G., Ruiz del Castillo M.L., Blanch G.P., Herraiz M.: Detection of the adulteration of olive oils by solid phase microextraction and multidimensional gas chromatography. Food Chemistry, 2006, 97 (2), 336-342.

[15] Guillén M.D., Cabo N.: Fourier transform infrared spectra data versus peroxide and anisidine values to determine oxidative stability of edible oils. Food Chemistry, 2002, 77 (4), 503-510.

[16] ISO 3961:2018. Animal and vegetable fats and oils. Determination of iodine value.

[17] ISO 5508:1990. Animal and vegetable fats and oils. Analysis by gas chromatography of methyl esters of fatty acids.

[18] Sharma H.K., Kaur B., Sarkar B.Ch., Singh C.: Thermal behavior of pure rice bran oil, sunflower oil and their model blends during deep fat frying. Grasas y Aceites, 2006, 57 (4), 376-381.

[19] Majchrzak T., Lubinska M., Różańska A., Dymerski T., Gębicki J., Namieśnik J.: Thermal degradation assessment of canola and olive oil using ultra-fast gas chromatography coupled with chemometrics. Monatsh. Chem., 2017, 148 (9), 1625-1630.

[20] Marinova E.M., Seizova K.A., Totseva I.R., Panayotova S., Marekov I., Momchilova S.: Oxidative changes in some vegetable oils during heating at frying temperature. Bulgarian Chemical Communications, 2012, 44, 57-63.

[21] Mujeeda B., Prasad N., Siddaramaiah: Effect of antioxidant on thermal stability of vegetable oils by using ultrasonic studies. Intern. Food Res. J., 2016, 23 (2), 528-536.

[22] Reena M.B., Reddy S.R.Y., Lokesh B.R.: Changes in triacylglycerol molecular species and thermal properties of blended and interesterified mixtures of coconut oil or palm oil with rice bran oil or sesame oil. Eur. J. Lipid Sci. Technol., 2009, 111 (4), 346-357.

[23] Shahidi F. (Ed.): Bailey's Industrial Oil and Fat Products: Edible Oil and Fat Products. John Wiley \& Sons, Hoboken, NJ, USA, 2005.

[24] Tan C.P., Che Man Y.B., Jinap S., Yusoff M.S.A.: Effects of microwave heating on changes in chemical and thermal properties of vegetable oils. JAOCS, 2001, 78 (12), 1227-1232.

[25] Tekin L., Aday M.S., Yilmaz E.: Physicochemical changes in hazelnut, olive pomace, grapeseed and sunflower oils heated at frying temperatures. Food Sci. Technol. Res., 2009, 15 (5), 519-524.

[26] Tiwari M.R., Tiwari K.K., Toliwal S.D.: Studies on thermal stability of palm-sesame oil blends during deep fat frying. J. Sci. Ind. Res., 2014, 73, 153-156.

[27] Turek C., Stintzing F.C.: Stability of essential oils: A review. Comprehensive Rev. Food Sci. Food Safety, 2013, 12 (1), 40-53.

[28] Ulusoy B.O., Karabulut I., Turan S.: Performance of some edible oils during heating in a steam pressure cooker. J. Food Lipids, 2004, 11 (3), 234-241.

[29] Vaskova H., Buckova M.: Thermal degradation of vegetable oils: Spectroscopic measurement and analysis. Procedia Engineering, 2015, 100, 630-635.

[30] Yáńez-Limŏn J.M., Mayen-Mondragŏn R., Martinez-Flores O., Flores-Farias R., Ruiz F., AraujoAndrade C., Martinez J.R.: Thermal diffusivity studies in edible commercial oils using thermal lens spectroscopy. Superficies y Vacío, 2005, 18, 31-37. 


\title{
ZASTOSOWANIE REGULY ADDYTYWNOŚCI DO WYZNACZANIA WLAŚCIWOŚCI FIZYKOCHEMICZNYCH MIESZANEK OLEJOWYCH ZE ZNANYCH PARAMETRÓW OLEJÓW SKŁADOWYCH
}

\author{
Streszczenie
}

W pracy zaproponowano procedurę wytwarzania mieszanin olejów roślinnych o pożądanych właściwościach fizykochemicznych i użytkowych. Zastosowano regułę addytywności parametrów składowych mieszaniny do uzyskania produktu tłuszczowego o zmodyfikowanych właściwościach żywieniowych. Zamierzeniem pracy było również przetestowanie użyteczności tej procedury do przewidywania właściwości termicznych mieszanek stosowanych do smażenia w głębokim oleju.

Do wytwarzania mieszanek użyto olejów roślinnych wyprodukowanych przez firmę Oleofarm. Mieszanki olejowe badano metodami chromatograficznymi i spektroskopowymi. Ich parametry chemiczne stanowiły zestaw danych wejściowych do tworzenia mieszanin o oczekiwanych właściwościach użytkowych. Wykazano eksperymentalnie, że parametry fizykochemiczne i termiczne końcowej mieszaniny olejów można teoretycznie przewidzieć. Gdy znane są parametry chemiczne indywidualnych olejów tworzących tę mieszaninę, można je użyć do wyznaczenia parametrów finalnej mieszaniny. Zaproponowano składy olejów do przygotowania korzystnych mieszanek do głębokiego smażenia i sosów sałatkowych. Tym samym potwierdzono zasadność mieszania olejów do wytwarzania produktów o cechach dostosowanych do konkretnych celów użytkowych.

Słowa kluczowe: olej roślinny, mieszaniny olejów, reguła addytywności, FT-IR/ATR 